\title{
Electrical Energy Efficiency Reviewed Study Room Lighting using Fuzzy Logic Method
}

\author{
Jusuf L. Mappadang \\ Electrical Engineering Dept \\ Manado State Polytechnic \\ North Sulawesi - Indonesia
}

\author{
Johan Pongoh \\ Electrical Engineering Dept \\ Manado State Polytechnic \\ North Sulawesi - Indonesia
}

\author{
Daud Salemba \\ Electrical Engineering Dept \\ Manado State Polytechnic \\ North Sulawesi - Indonesia
}

\begin{abstract}
The lighting in the workplace especially on the lecture hall is an important aspect to support teaching and learning activities. Lighting that does not meet minimum standards can cause eye health disorders.
\end{abstract}

Fuzzy logic control in this system can control and maintain stability based on a given set point despite the change in intensity of room lighting.

The system can correct the error in the amount of 150 lux, by controlling the control voltage of 5 volts so that the intensity of the ambient light remains in the position set point.

The cost of electrical energy consumption after optimization of $52.38 \%$, resulting in cost savings of electrical energy consumption amounted to $47.62 \%$.

\section{General Terms}

Control System, Fuzzy Logic, electrical energy.

\section{Keywords}

Optimization, Lighting Room, Dimer, Light Sensor

\section{INTRODUCTION}

Natural lighting is the light source comes from the sun. To get natural light into a space required large windows or glass walls. Natural lighting sources are sometimes less effective than the use of artificial lighting because of the intensity of light is not fixed. Artificial lighting is the lighting generated by the light source in addition to natural light. Artificial lighting is necessary if the position of the room difficult to achieve by natural lighting or when natural lighting is insufficient. [1]

The quantity and quality of good lighting is determined from the light reflection rate and the ratio of lighting in the room. In addition to quantity and quality aspects of lighting should also pay attention to aspects of energy consumption efficiency by utilizing natural light for economic gain. Natural light coming in through the window, can be used as a source of lighting in the building as well as efforts to conserve energy. [3]

The energy needs of the world from year to year increases exponentially. It is estimated that in 2035 increased nearly four-fold of the energy needs in 2010. Approximately $24 \%$ of the total energy used by buildings, and $35.8 \%$ of energy in buildings used for lighting systems. [6]

Energy efficiency and visual comfort is the key word in lighting design school. The balance of direct and indirect light provided enough in the classroom to support students to work on a task-oriented and computer paper with good. [2]
Optimization study room lighting is required so that students and teachers can do activities with either indoors, efficiency in the consumption of electrical energy and visual comfort. Energy use is good is according to the needs.

There are several ways to achieve efficiency of electricity consumption of artificial lighting are: the installation of the controller on the lights, grouping dots to switch lamps, luminaires use appropriate, the use of natural light, operation and maintenance of lighting systems. [3]

\section{BASIC THEORY}

\subsection{Lighting room}

The level of illumination in a room is generally defined as the average lighting level in a work plane. Average lighting level calculated by the equation. [4]

Where

$$
\mathrm{E}_{\text {average }}=\frac{\mathrm{F}+\mathrm{K}_{\mathrm{p}}+\mathrm{K}_{\mathrm{d}}}{\mathrm{A}}
$$

$$
\begin{array}{ll}
\mathrm{E}_{\text {average }} & : \text { lighting average (lux) } \\
\mathrm{F}_{\text {total }} & : \text { Fluks luminous total (lumen) } \\
\mathrm{A} & : \text { Large }\left(\mathrm{m}^{2}\right) \\
\mathrm{K}_{\mathrm{p}} & : \text { Coefficient of Use } \\
\mathrm{K}_{\mathrm{d}} & : \text { Coefficient depression }
\end{array}
$$

index of room needed to know how big the room lighting needs. Index of room or index of form $\mathrm{k}$ states the comparison between the main measures of a square room. [4]

Where

$$
\mathrm{k}=\frac{\mathrm{p} \times \mathrm{l}}{\mathrm{h}(\mathrm{p}+\mathrm{l})}
$$

$$
\begin{array}{ll}
\mathrm{k} & : \text { index of the room } \\
\mathrm{p} & : \text { the length of the room (meters) } \\
\mathrm{l} & : \text { width of the room (meters) } \\
\mathrm{h} & \text { : height working plane (meters) }
\end{array}
$$

If the $\mathrm{k}$ values obtained are not included in Table 1 , the efficiency of the lighting can be determined by interpolation.

$$
\mathrm{K}_{\mathrm{p}}=\mathrm{K}_{\mathrm{p} 1} \frac{\mathrm{K}-\mathrm{K}_{1}}{\mathrm{~K}_{2}-\mathrm{K}_{1}}\left(\mathrm{~K}_{\mathrm{P} 1}-\mathrm{K}_{\mathrm{p} 2}\right)
$$

Rederasi minimum lighting levels and colors for the various functions of the room is determined based on Table 2. Flux light needed can be calculated by the equation. [4]

$$
\mathrm{F}=\frac{\mathrm{ExA}}{\eta} \text {, new condition }
$$

or

$$
F=\frac{E \times A}{\eta \times d}, \text { to have been used }
$$

Where

$$
\eta \text { : Efficiency }
$$


Table 1. Efficiency of the lighting

\begin{tabular}{|c|c|c|c|c|c|c|c|c|c|c|c|c|c|}
\hline \multicolumn{12}{|c|}{ Efficiency lighting to new circumstances } & \multicolumn{2}{|c|}{$\begin{array}{l}\text { Depression factor for } \\
\text { the maintenance period }\end{array}$} \\
\hline \multirow{3}{*}{$\begin{array}{c}\text { Armature direct } \\
\text { illumination }\end{array}$} & $\mathrm{V}$ & $\mathrm{k}$ & rp & 0.7 & & & 0.5 & & & 0.5 & & 1 year & 2 years \\
\hline & & rw & 0.5 & 0.3 & 0.1 & 0.5 & 0.3 & 0.1 & 0.5 & 0.3 & 0.1 & & \\
\hline & $\%$ & & $\mathrm{rm}$ & 0.1 & & & 0.1 & & & 0.1 & & & \\
\hline \multicolumn{2}{|l|}{ GCB } & 0.5 & 0.26 & 0.2 & 0.17 & 0.22 & 0.18 & 0.15 & 0.19 & 0.16 & 0.14 & Mild f & \\
\hline \multicolumn{2}{|l|}{$2 \times \mathrm{TL} 40 \mathrm{w}$} & 0.6 & 0.3 & 0.25 & 0.21 & 0.26 & 0.22 & 0.19 & 0.23 & 0.19 & 0.17 & 0.85 & 0.8 \\
\hline \multirow[t]{3}{*}{ Parallel roster } & & 0.8 & 0.38 & 0.32 & 0.28 & 0.33 & 0.29 & 0.25 & 0.28 & 0.25 & 0.23 & Foulin & \\
\hline & & 1 & 0.43 & 0.38 & 0.34 & 0.38 & 0.34 & 0.3 & 0.32 & 0.29 & 0.27 & 0.8 & 0.27 \\
\hline & & 1.2 & 0.47 & 0.42 & 0.38 & 0.41 & 0.37 & 0.34 & 0.35 & 0.32 & 0.3 & Heavy & \\
\hline \multirow[t]{6}{*}{ 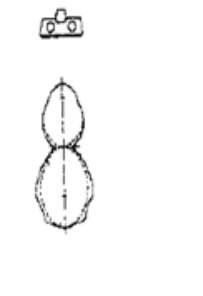 } & & 1.5 & 0.51 & 0.47 & 0.43 & 0.45 & 0.41 & 0.38 & 0.38 & 0.36 & 0.33 & $\mathrm{x}$ & $\mathrm{x}$ \\
\hline & 38 & 2 & 0.56 & 0.52 & 0.49 & 0.49 & 0.46 & 0.43 & 0.42 & 0.4 & 0.38 & & \\
\hline & & 2.5 & 0.59 & 0.56 & 0.52 & 0.52 & 0.49 & 0.46 & 0.44 & 0.42 & 0.4 & & \\
\hline & 81 & 3 & 0.61 & 0.58 & 0.55 & 0.54 & 0.51 & 0.49 & 0.46 & 0.44 & 0.42 & & \\
\hline & & 4 & 0.64 & 0.62 & 0.59 & 0.56 & 0.54 & 0.52 & 0.48 & 0.47 & 0.45 & & \\
\hline & 43 & 5 & 0.66 & 0.64 & 0.62 & 0.58 & 0.56 & 0.54 & 0.5 & 0.48 & 0.47 & & \\
\hline
\end{tabular}

Table 2. Minimum lighting levels and color rederation are recommended

\begin{tabular}{|c|c|c|c|}
\hline Function room & $\begin{array}{c}\text { Lighting } \\
\text { levels (lux) }\end{array}$ & $\begin{array}{c}\text { The color } \\
\text { rederation group }\end{array}$ & Explanation \\
\hline \multicolumn{4}{|l|}{ Residential home: } \\
\hline Terrace & 60 & 1 or 2 & \\
\hline Living room & $120-250$ & 1 or 2 & \\
\hline The dining room & $120-250$ & 1 or 2 & \\
\hline Workspace & $120-250$ & 1 & \\
\hline badroom & $120-250$ & 1 or 2 & \\
\hline bathroom & 250 & 1 or 2 & \\
\hline Kitchen & 250 & 1 or 2 & \\
\hline Garage & 60 & 3 or 4 & \\
\hline \multicolumn{4}{|l|}{ Office complex: } \\
\hline Boardroom & 350 & 1 or 2 & \\
\hline Workspace & 350 & 1 or 2 & \\
\hline Computer room & 350 & 1 or 2 & $\begin{array}{l}\text { Use latticed armature to prevent glare due to } \\
\text { reflections screen }\end{array}$ \\
\hline Meeting room & 300 & 1 or 2 & \\
\hline The drawing room & 750 & 1 or 2 & use local lighting on the table image \\
\hline Archive room & 150 & 3 or 4 & \\
\hline \multicolumn{4}{|l|}{$\begin{array}{l}\text { Educational } \\
\text { institutions: }\end{array}$} \\
\hline Classroom & 250 & 1 or 2 & \\
\hline Library room & 300 & 1 or 2 & \\
\hline Laboratory & 500 & 1 & \\
\hline The drawing room & 750 & 2 & use local lighting on the table image \\
\hline Canteen & 200 & 1 & \\
\hline \multicolumn{4}{|l|}{ Hotels and restaurants: } \\
\hline Lobby, corridor & 100 & 1 & $\begin{array}{l}\text { Lighting in the vertical plane is very important to } \\
\text { create an atmosphere / space a good impression }\end{array}$ \\
\hline Ballroom/court room & 200 & 1 & $\begin{array}{l}\text { Lighting systems should be designed to create an } \\
\text { appropriate atmosphere. switching and dimming } \\
\text { control system can be used to obtain a variety of } \\
\text { lighting effects }\end{array}$ \\
\hline The dining room & 250 & 1 & \\
\hline Cafeteria & 250 & 1 & \\
\hline Badroom & 150 & 1 or 2 & $\begin{array}{l}\text { required additional light on this part of the headboard } \\
\text { and mirror }\end{array}$ \\
\hline Kitchen & 300 & 1 & \\
\hline hospital/clinic: inpatient & 250 & 1 or 2 & \\
\hline
\end{tabular}


The amount of light or the armature is required:

$$
\mathrm{n}=\frac{\mathrm{E} \times \mathrm{A}}{\mathrm{F}_{\operatorname{lamp} \times \mathrm{n} \times \mathrm{d}}}
$$

Where

$$
\mathrm{n}: \text { Number armature or lamp }
$$

\subsection{Fuzzy logic}

Fuzzy logic is a fundamental model of the relationship between input and output consists of four components. [5]

1. Fuzzy knowledge base is a collection of fuzzy rulerule in the form of IF ... THEN statement.

2. Fuzzification process to change the input value system that has firmly become linguistic variables using membership functions stored in a fuzzy knowledge base.

3. An inference engine is a process for converting input into output fuzzy by following the rules defined in the fuzzy knowledge base.
4. Defuzzufikasi is the process of converting into a fuzzy output value of assertive.

Some of the membership functions are often used in fuzzy logic include triangle and trapezoid membership functions. [5]

\subsubsection{Triangle membership function.}

Membership Function Triangle is a combination of two pieces of linear line as shown in Fig. 1.

Membership functions:

$$
\mu(x)=\left\{\begin{array}{l}
0, x \leq a \text { or } x \geq c \\
\frac{x-a}{b-a}, a \leq x \leq b \\
\frac{c-x}{c-a}, \quad b \leq x \leq c \\
1, \quad x=b
\end{array}\right.
$$

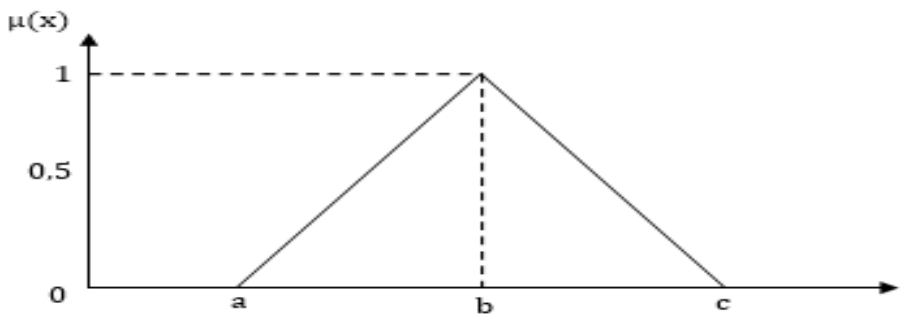

Fig. 1. Graph of triangle membership function

\subsubsection{Trapezoid membership function}

Membership Function trapezium is essentially like a triangular shape, it's just that there are a few points that have membership value 1 as shown in Fig. 2.
Membership functions:

$$
\mu(x)=\left\{\begin{array}{lc}
0, x \leq a \text { atau } x \geq d \\
\frac{x-a}{b-a}, \quad a \leq x \leq b \\
\frac{d-x}{d-c}, \quad c \leq x \leq d \\
1, \quad b \leq x \leq c
\end{array}\right.
$$

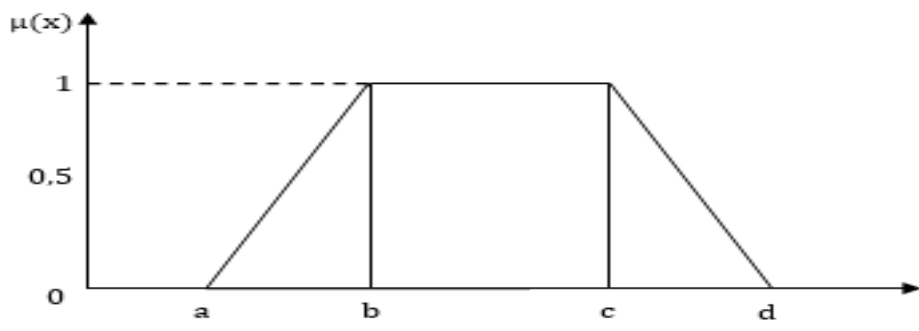

Fig. 2. Trapezoidal membership function graph

\section{RESEARCH METHODS}

\subsection{Control system}

Block diagram of the control system of learning room lighting intensity can be seen in Fig. 3. The control signal V is a signal generated by the controller Fuzzy Logic Control (FLC) is used to control voltage electronic ballast (dimer).
Dimer will arrange artificial lighting (fluorescent lamp) and I-Set Point is the desired light intensity. Signal information received by the controller FLC is a signal Error (E) and the change in Error (dE).

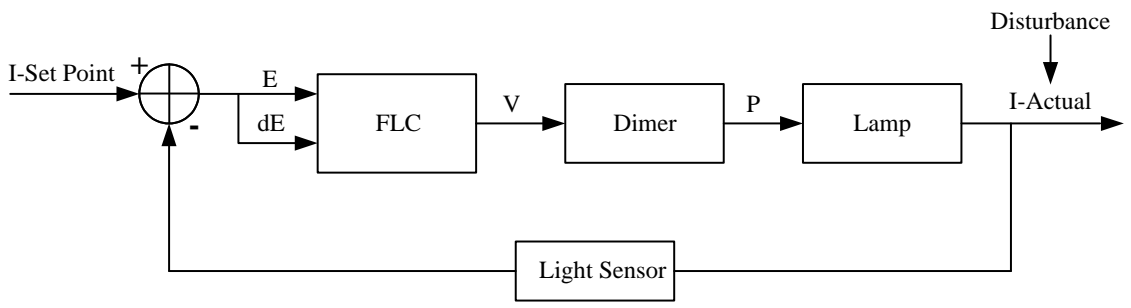

Fig. 3. Block diagram of the intensity of the control system 


\subsection{Measurement of light}

Cut-off point of taking the measurements refer to the SNI (Standart Nasional Indonesia) 16-7062-2004 (Illumination Intensity Measurements at Work), with an area of $52.5 \mathrm{~m} 2$ room, a distance of the point of intersection horizontal line the length and width of the room is within 3 meters. Sketch of measurement of lecture room 01 Department of Electrical Engineering Manado State Polytechnic can be seen in Fig. 4.

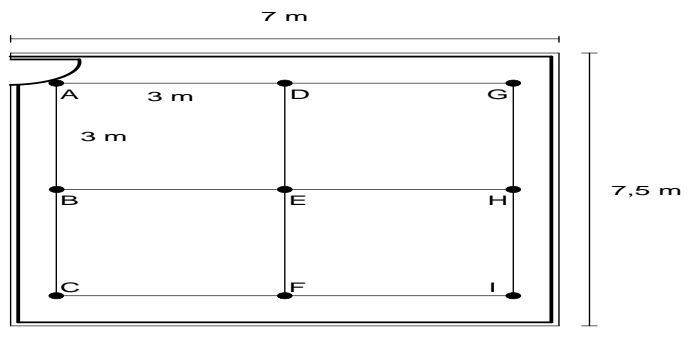

Fig. 4. Sketch of the lecture room measurement

Measurement of light intensity at the lecture hall 01 was made on July 1, 2016, Measurement data of natural light intensity as shown in Table 3. Data from the measurement of the intensity of natural lighting and artificial lighting as shown in Table 4.

Table 3. Intensitas lighting without artificial illumination, measurement at 11:30

\begin{tabular}{|l|l|l|l|l|}
\hline \multirow{2}{*}{} & \multicolumn{3}{|l|}{ Measurement results (Lux) } & \multirow{2}{*}{ Average (Lux) } \\
\cline { 2 - 4 } & Column A & Column D & Column G & \\
\hline Row A & 180 & 142 & 116 & 146 \\
\hline Row B & 156 & 127 & 112 & 131.66 \\
\hline Row C & 190 & 153 & 121 & 154.66 \\
\hline
\end{tabular}

Note: $\leq 250 \leq 500$ lux lighting is good; lux $<250$ poor lighting; lux $>500$ redundant

Table 4. Intensity of illumination with artificial lighting, measurement at 11:37

\begin{tabular}{|l|l|l|l|l|}
\hline & \multicolumn{3}{|c|}{ Measurement results (Lux) } & \multirow{2}{*}{$\begin{array}{c}\text { Average } \\
\text { (Lux) }\end{array}$} \\
\cline { 2 - 4 } & Column A & Column D & Column G & 329,66 \\
\hline Row A & 376 & 324 & 289 & 329,66 \\
\hline Row B & 338 & 320 & 276 & 311,33 \\
\hline Row C & 388 & 374 & 303 & 355 \\
\hline
\end{tabular}

Note: $\leq 250 \leq 500$ lux lighting is good; lux $<250$ poor lighting; lux $>500$ redundant

\subsection{Room lighting system}

To determine the strong illumination of the room, first determined the type of lamp and armature that will be used. Room indices needed to know how big the room lighting needs. Based on the equation (2) obtained by the index of the room:

$$
\begin{aligned}
& \mathrm{k}=\frac{7,5 \times 7}{2,6(7,5+7)} \\
& \mathrm{k}=1,39
\end{aligned}
$$

Because $\mathrm{k}$ is not contained in Table $1, \mathrm{k}$ sought by interpolation with wall reflection factor $\mathrm{rp}=0.7$, wall reflection factor sky-lngit $\mathrm{rw}=0.5$, the reflection factor floor $\mathrm{rm}=0.1$, for $\mathrm{k}_{1}=1.2$ obtained $\eta=0.47$ and $\mathrm{k}_{2}=1.5$ with efficiency $\eta=0.51$, based on the equation (3) obtained $\mathrm{K}_{\mathrm{p}}$.

$$
\begin{aligned}
\mathrm{k}_{\mathrm{p}} & =0,47+\frac{1,39-1,2}{1,5-1,2}(0,51-0,47) \\
& =0,495
\end{aligned}
$$

Luminous flux is required can be calculated based on the equation (5). Lamps used in this study is the TL - D 36W with luminous flux of 2500 lumens (catalog).

$$
\mathrm{F}_{\text {armature }}=2500 \text { lumen }
$$

Based on powerful lighting Table 2 study rooms ranging between $250 \mathrm{~s} / \mathrm{d}$. 500 lux, as a sample was taken of 300 lux. The number of bulbs or armatures $\mathrm{n}$ needed is determined from equation (6).

$$
\begin{aligned}
\mathrm{N} & =\frac{\mathrm{E} \times \mathrm{A}}{\mathrm{F}_{\text {lampu }} \times \mathrm{n} \times \mathrm{d}}=\frac{300 \times 52,5}{2500 \times 0,495 \times 0,85} \\
& =14,97 \approx 14
\end{aligned}
$$

Electrical energy consumption for one year assuming the lecture conducted 8 months and in 1 month is 22 days college, then consumption of electrical energy:

$$
\begin{aligned}
\text { Electrical energy } & =14 \times 22 \times 8 \times 36 \\
& =84,672 \mathrm{KWh}
\end{aligned}
$$

Cost of electric energy consumption:

$$
\begin{aligned}
\text { Cost } & =\text { electrical energy } \mathrm{x} \text { cost per } \mathrm{KWh} \\
\text { Cost } & =\text { electrical energy } \times \text { cost per KWh } \\
\text { Cost } & =84,72 \times \text { Rp. } 1.412 .66 \\
& =\text { Rp } 119.612 .75
\end{aligned}
$$

\subsection{Fuzzy logic control system}

Room light intensity settings automatically use control system that can regulate voltage electronics balasst 36 Watt fluorescent lamp. This control system is affected by two inputs, namely Error (E), Delta Error (dE) and Voltage as balasst controller electronics. Based on datasheet, controlling the voltage range between $1 \mathrm{~s} / \mathrm{d} 10$ Volt. The design of the controller with Fuzzy Logic in this study using Tsukamoto.

The fuzzy input used is Error (E) and error change (dE), while the fuzzy controller ouput is voltage $(\mathrm{V})$. For input error $(\mathrm{E})$ and output voltage $(\mathrm{V})$ have the same linguistic variables Negative $(\mathrm{N})$, Zerro $(\mathrm{Z})$ and Positive $(\mathrm{P})$, while the Error change input $(\mathrm{dE})$ has linguistic variables of $\mathrm{Ng}, \mathrm{Ze}$ and Ps. The operation of the relationship between $\mathrm{E}$ and $\mathrm{dE}$ is used by AND operator to obtain a fuzzy control rule base as in Table 5 
Table 5. Fuzzy rule base

\begin{tabular}{|c|c|c|c|c|}
\hline \multicolumn{2}{|c|}{} & \multicolumn{3}{|c|}{$\mathbf{d E}$} \\
\cline { 3 - 5 } \multicolumn{2}{|c|}{} & Ng & Ze & Ps \\
\hline \multirow{3}{*}{$\mathbf{E}$} & $\mathbf{N}$ & $\mathrm{N}$ & $\mathrm{N}$ & $\mathrm{Z}$ \\
\cline { 2 - 5 } & $\mathbf{Z}$ & $\mathrm{N}$ & $\mathrm{Z}$ & $\mathrm{P}$ \\
\cline { 2 - 5 } & $\mathbf{P}$ & $\mathrm{Z}$ & $\mathrm{P}$ & $\mathrm{P}$ \\
\hline
\end{tabular}

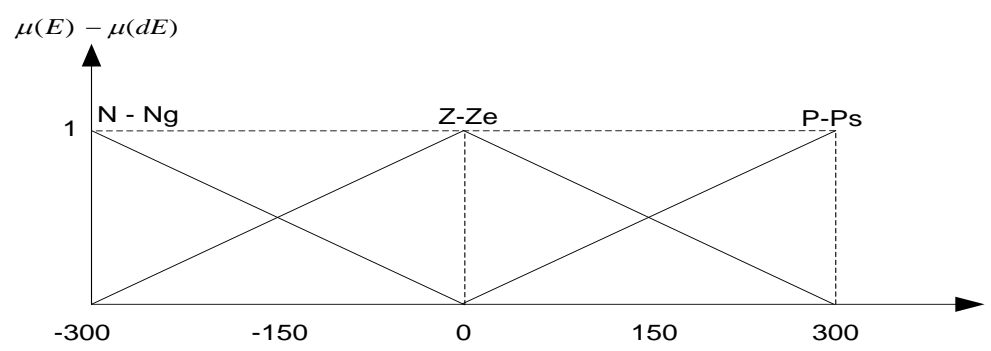

Fig. 5. Membership function input Error (E) and delta Error (dE)

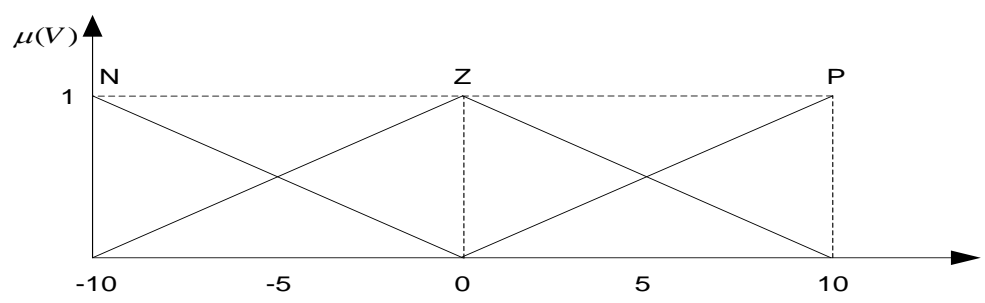

Fig. 6. Membership function control output signal (v)

\section{RESULTS AND DISCUSSION}

The initial condition of the test, assuming the intensity of the set point is equal to the actual intensity, so that $\mathrm{E}=0$ and $\mathrm{dE}=0$, then tested with a decrease in the intensity of 150 lux, yields $E=150$ lux and Change $E=150$. fuzzy logic will be searched for control signal voltage value To increase the actual intensity to the set point position as follows:

\subsection{Fuzzyfikasi}

Membership Function Error:

$$
\begin{aligned}
& M_{Z}(E)=0,5 \\
& \mu_{P}(E)=0,5
\end{aligned}
$$

Membership Function delta Error (dE).

$$
\begin{aligned}
& \mu_{\mathrm{Z}}(\mathrm{dE})=0,5 \\
& \mu_{\mathrm{P}}(\mathrm{dE})=0,5
\end{aligned}
$$

Membership Function control signal (v)

$$
\begin{aligned}
& \mu_{\mathrm{Z}}(\mathrm{v})=\left\{\frac{10-\mathrm{v}}{10-0}=0,5\right. \\
& \mu_{\mathrm{P}}(\mathrm{v})=\left\{\frac{\mathrm{x}-0}{10-0}=0,5\right.
\end{aligned}
$$

\subsection{Rule}

Formation rule for testing each intensity value can be adjusted in Table 5 .
$(\mathrm{R} 1) \rightarrow \mathrm{IF}$ E is P AND dE is Ps Then $\mathrm{v}$ is $\mathrm{P}$
$(\mathrm{R} 2) \rightarrow \mathrm{IF}$ E is P AND dE is ze Then $v$ is $P$
$(\mathrm{R} 3) \rightarrow \mathrm{IF}$ E is Z AND dE is Ps Then $\mathrm{v}$ is $\mathrm{P}$
$(\mathrm{R} 4) \rightarrow$ IF E is $Z$ AND dE is ze Then $\mathrm{v}$ is $\mathrm{Z}$

\subsection{Inference engine}

Based on the established rule, the MIN function is applied to each rule on the application functionality implications.
R1 obtainable: $\alpha$ - predikat $_{1}=0,5$

$$
\begin{aligned}
& \mu_{\mathrm{P}}(\mathrm{v})=\left\{\frac{\mathrm{x}-0}{10-0}=0,5\right. \\
& \mathrm{v}_{1}=5
\end{aligned}
$$

R2 obtainable: $\alpha$ - predikat $_{2}=0,5$

$$
\begin{aligned}
& \mu_{P}(v)=\left\{\frac{x-0}{10-0}=0,5\right. \\
& v_{2}=5
\end{aligned}
$$

R3 obtainable: $\alpha-$ predikat $_{3}=0,5$

$$
\begin{aligned}
& \mu_{P}(v)=\left\{\frac{x-0}{10-0}=0,5\right. \\
& v_{3}=5
\end{aligned}
$$

R4 obtainable: $\alpha-$ predikat $_{4}=0,5$

$$
\begin{aligned}
& \mu_{\mathrm{Z}}(\mathrm{v})=\left\{\frac{10-\mathrm{v}}{10-0}=0,5\right. \\
& \mathrm{v}_{4}=5
\end{aligned}
$$

\subsection{Defuzzification}

Value firm output voltage (v) can be searched using a weighted average:

$$
\begin{aligned}
& \mathrm{v}=\frac{\propto_{1} * \mathrm{v}_{1}+\propto_{2} * \mathrm{v}_{2}+\propto_{3} * \mathrm{v}_{3}+\propto_{4} * \mathrm{v}_{4}}{\propto_{1}+\propto_{2}+\propto_{3}+\propto_{4}} \\
& \mathrm{v}=\frac{0,5 * 5+0,5 * 5+0,5 * 5+0,5 * 5}{0,5+0,5+0,5+0,5} \\
& \mathrm{v}=5 \text { Volt }
\end{aligned}
$$

Based on the results of fuzzy logic testing using Stsukamoto method with error 150 lux, thus to achieve the intensity of 300 lux set point is required additional lighting from the artificial lighting of 150 lux with calculation of the cost of electric energy consumption after the optimization as follows:

The consumption cost of electricity for one year can be calculated as follows:

$$
\text { Electrical energy }=14 \times 22 \times 8 \times 18
$$$$
=44,352 \mathrm{KWh}
$$ 
The cost of electrical energy consumption:

$$
\begin{aligned}
\text { cost } & =\text { electrical energy } \times \text { cost per KWh } \\
\text { cost } & =44,352 \times \text { Rp. } 1.412 .66 \\
& =\text { Rp } 62.654 .30,-
\end{aligned}
$$

Comparison of the cost of electricity consumption

Difference in cost $=\mathrm{Rp} 119.612 .75-\mathrm{Rp} 62.654 .30$

$$
=\operatorname{Rp} 56.958 .45
$$

cost of electricity consumption $(\%)=\frac{62.654 .30}{119.612 .75} \times 100 \%$

$$
=52.38 \%
$$

Cost savings in electricity consumption $=47.62 \%$

\section{CONCLUSION}

After testing in this study, it can be concluded that the fuzzy logic control in this system can control and maintain stability based on a given set point despite the change in intensity of room lighting.

Based on the disturbance given with a 150 lux error, the system can fix the error by controlling the 5 volt control voltage so that the light intensity of the room remains in the set point position.

The cost of electrical energy consumption after optimization of $52.38 \%$, resulting in cost savings of $47.62 \%$.

\section{REFERENCES}

[1] Amin, Nurhani. 2011. Optimasi Sistem Pencahayaan dengan Memanfaatkan Cahaya Alami (Studi Kasus Lab. Elektronika dan Mikroprosessor Untad). Jurusan Teknik Elektro Universitas Tadulako Palu. Jurnal Ilmiah Foristek Vol.1, no. 1, Maret 2011.

[2] Dora, Purnama Esa. 2011. Optimasi Desain Pencahayaan Ruang Kelas SMA Santa Maria Surabaya. Jurusan Desain Interior, Fakultas Seni dan Desain. Universitas Kristen Petra. Surabaya: Dimensi Interior, Vol. 9, No. 2, Desember 2011: 69-79 70.

[3] Irianto, Chairul Gagarin. 2006. Studi Optimasi Sistem Pencahayaan Ruang Kuliah dengan Memanfaatkan Cahaya Alam. Jurusan Teknik Elektro-FTI, Universitas Trisakti Jakarta: Jetri, Volume 5, nomor 2, Februari 2006, Halaman 1-20.

[4] SNI, 2001. Tata cara perancangan sistem pencahayaan buatan pada bangunan gedung. SNI 03-6575-2001.

[5] T. Sutojo, Edy M., and Vincent S. 2011. Kecerdasan Buatan. Penerbit Andi Yogyakarta.

[6] Yang, In-Ho. 2010. Economic Analysis of the DaylightLinked Lighting Control Sistem in Office Buildings. Elsevier, 2010: 1513-1525. 